\title{
Estimation of radiation doses for transition from emergency to existing exposure situation
}

\author{
Abdelfatah A. Hamed, \\ E. F. Salem, \\ Asmaa K. Abdien
}

\begin{abstract}
The transition from emergency to existing exposure situation is an important stage in the nuclear or radiological emergency plan. It requires arrangements to be put in place and to be implemented so as to ensure that the transition is made in a coordinated and orderly manner of guidelines for adjusting the undertaken protective actions and other response actions. The delivering radiation doses to public and environmental pollution are monitoring that measurements should be implemented according to certain plan of intervention and protective actions in the different stages of the N/R accident. In this study, a computer model (RASCAL) is used to calculate the effect of severe accident could have detected on an operating nuclear power reactor PWR and the possible impact on the public. Features for the decision to implement the transition from emergency to existing exposure situation are proposed depending on the estimation of the collection of deliver exposure doses to the public and environment due to monitoring the different radiation sources resulting from the $\mathrm{N} / \mathrm{R}$ accident.
\end{abstract}

Key words: nuclear emergency • emergency computer code $\bullet$ severe accident

\author{
A. A. Hamed ${ }^{\bowtie}$, E. F. Salem, A. K. Abdien \\ Egypt Nuclear and Radiological Regulatory Authority, \\ Nasr City, P. O. Box 7551, Cairo, Egypt, \\ E-mail: Hamed243@yahoo.com
}

Received: 19 August 2013

Accepted: 24 October 2014

\section{Introduction}

Till date, there have been five serious nuclear accidents (core damage) in the world since 1970 (one at Three Mile Island in 1979; one at Chernobyl in 1986; and three at Fukushima-Daiichi in 2011), corresponding to the beginning of the operation of generation II reactors [1]. This leads to on average one serious accident happening every 8 years worldwide. The overall emergency management can be divided into three phases, i.e. preparedness, response and recovery; however the response phase can be subdivided into early and intermediate responses, in which the response and recovery phases are corresponding to the concepts of emergency and existing exposure situations, respectively, as provided by the ICRP 2007 Recommendations [2]. The change from an emergency exposure situation to an existing exposure situation will be based on a decision by the authority responsible for the overall response. The transfer should be undertaken in a coordinated and fully transparent manner, and should be understood by all parties involved [3]. In general, offsite protective measures should be prepared when dose consequences are estimated above a low level of emergency protective guidelines, $10 \mathrm{mSv}$ for whole body and $50 \mathrm{mSv}$ for thyroid at the site boundary after any accident. The output data from a computerized program shall provide to decision-makers, for on-site and off-site, the necessary 
technical elements for determining the appropriate countermeasures, by anticipating, as far as possible, the occurrence of releases into the environment. Radiological Assessment System for Consequence Analysis (RASCAL) is the software program developed and used by Emergency Operations Center, US Nuclear Regulatory Commission (NRC), to estimate projected doses from radiological emergencies [4]. In the next sections (input and output data), there is an explanation how RASCAL model estimate and analyse the accident consequences in detail. Also, this program is used to reliably predict source term in case of an accident in a light-water reactor (LWR), taking into account the information available on the plant. An accident occurs in nuclear reactor when the cooling water systems of the plant are no longer removing heat from the reactor fuel (the 'core' of the reactor). Extensive core damage could melt reactor fuel, which would settle at the bottom of the reactor vessel that is designed to hold the fuel. The reactor vessel is surrounded by the containment building. If cooling water is not restored, however, and the accident progresses further, the melted fuel could rupture the bottom of the reactor vessel, with flowing of the melted fuel onto the containment floor. Radioactive material would be released from the fuel into the containment atmosphere and could potentially escape from the containment if there were any available leakage paths [5]. The International Commission on Radiological Protection (ICRP) has indicated that its basic framework for radiological protection is intended to prevent the occurrence of deterministic effects, by keeping doses below the relevant thresholds, and to ensure that all reasonable steps are taken to reduce the induction of stochastic effects [6]. According to the ICRP, the protection of the public in existing exposure situations should follow the system of protection for interventions. Within the system of protection, an intervention is defined as, any action intended to reduce or avert exposure or the likelihood of exposure to sources, which are not part of a controlled practice or which are out of control as a consequence of an accident. The term intervention refers to those situations where the sources, pathways and exposed individuals are already in place when decisions about control measures are being considered.

\section{Simulation of the emergency action procedures}

A postulated nuclear power plant pressurized water reactor (PWR) $1000 \mathrm{MW}$ had been operating at full power. The reactor tripped due to a major rupture in the primary coolant system (loss-of-coolant accident - LOCA). The accident is classified as general emergency accident. The meteorological data is needed to predict the behavior of the radioactive plume in the atmosphere. The simulation goal is to provide the best representation of the weather conditions for running the model in both time and space. That is, capture how the conditions change with time over the period of the release, plume transport and the plume moves away from the release point.

\section{Input data}

\section{Atmospheric conditions}

The software program requires the initial weather data be entered within a period of $2 \mathrm{~h}$ (window) before the start of the release. For nuclear power plants, weather observations of the site itself would be obtained via the Emergency Response Data System (ERDS) or by telephone from the licensee. The weather data is measured on a multilevel tower. It consists of wind speed and direction, air temperature and atmospheric stability. The reporting interval may vary but is usually $15 \mathrm{~min}$, averaging interval. Note that precipitation of released radioisotopes is not measured or reported. Normally you will enter the data measured at the lowest tower level (typically $10 \mathrm{~m}$ or $30 \mathrm{ft}$ ). You can use elevated measurements, but it will need to change the height measurement in the program. For the purposes of this study, we assume that ERDS and the plant operators have provided that the wind speed $6 \mathrm{~m} / \mathrm{h}$ and wind direction $10^{\circ}$.

\section{Source term}

Operators believe that the core may become uncovered and they are concerned that they may not be able to provide enough makeup water to recover the core. Plant operators report that they are unable to activate the containment spray system. However, they expect the containment to remain intact and any release to the atmosphere will be at the design leak rate. Leak rate before intervention was $10 \% / \mathrm{h}$ and reduces to $0.1 \% / \mathrm{h}$ after $3 \mathrm{~h}$ from beginning of the accident. The total amount of radiation released to atmosphere before intervention is $3.2 \times 10^{18} \mathrm{~Bq}$, where $9.2 \times 10^{17} \mathrm{~Bq}$ after intervention.

\section{Output data}

\section{Cloudshine dose calculations}

First, the model calculates the composite characteristics (photon energies, photons per disintegration, etc.) of the gamma radiation emitted from the released radionuclides products mix in a puff. Next, the model calculates the dose rate vs. distance from a point source having the composite characteristics using the following Eqs. (1) and (2):

$$
D_{p}^{\prime}(\rho)=\frac{2.13 X 10^{6}}{4 \pi \rho^{2}} \sum_{\gamma}\left[f_{\gamma} B_{\gamma}\left(\mu_{\gamma}, \rho\right) e^{-\mu a \gamma \rho} E_{\gamma} T_{\gamma} W_{\gamma}\right]
$$

where: $D_{p}^{\prime}(\rho)$ is the dose rate in $(\mathrm{rem} / \mathrm{h}) / \mathrm{Ci} ; \rho$ is the distance from point source; $f_{\gamma}$ is the fraction of disintegrations producing $\gamma \mathrm{s}$ of energy, $E_{\gamma} ; B_{\gamma}\left(\mu_{\gamma}, \rho\right)$ is the buildup factor for air; $\mu_{a \gamma}$ is the linear attenuation factor for air; $E_{\gamma}$ is the gamma energy; $T_{\gamma}$ is the mass energy absorption coefficient for tissue $\left(\mu t_{\gamma} / \rho t\right)$; $W_{\gamma}$ is the ratio of whole-body dose to surface dose.

$$
D_{p}^{\prime}(r)=\sum_{i} \sum_{j} \sum_{k} D_{p}^{\prime}\left(\rho_{i j k}\right) M_{i j k}
$$


where: $D^{\prime}(r)$ is the dose rate at distance $r ; r$ is the distance from the receptor to the projection of the puff center on the ground; $i j k$ is the indices associated with the volume elements; $D_{p}^{\prime}\left(\rho_{i j k}\right)$ is the dose rate at distance $\rho$ from a point source in volume element $i j k ; \rho_{i j k}$ is the distance from the center of the volume element $i j k$ to the receptor; $M_{i j k}$ is the fraction of the total puff activity in volume element $i j k$.

\section{Organ committed dose equivalents due to inhalation}

Organ committed dose equivalents and committed effective dose equivalents are calculated for 15-min periods. These dose equivalents are the sum of integration doses due to exposure over all the released radionuclides products from the accident during the 15-min period interval, a radionuclide $n$ and organ specific dose conversion factor, and the breathing rate. The general expression for the organ-committed dose equivalents is:

$$
D_{15}=V_{b} \sum_{n}\left[\operatorname{DCF}_{n} \int_{t}^{t+15} \chi_{n}(t) d t\right]
$$

where: $D_{15}$ is the organ-committed dose equivalent due to inhalation during a period $15 \mathrm{~min} ; V_{b}$ is the breathing rate; $\mathrm{DCF}_{n}$ is the radionuclide $n$ and organ specific dose conversion factor; $\chi_{n}$ is the radionuclide $n$ concentration; $t$ is the time.

Total effective dose equivalent (TEDE) that the code calculates is the sum of the external gamma dose (cloudshine) from the plume, the committed effective dose equivalent (CEDE) and the integrated external dose over a 4-day-period interval from radionuclides $n$ deposited on the ground (4-day-groundshine dose).

\section{Groundshine doses}

RASCAL model calculates the groundshine dose equivalents as the sum of integration over all the surface contamination due to the released radionuclides products from the accident and a radionuclide-specific dose conversion factor. The general expression for the groundshine dose equivalent is:

$$
D_{g s}=\operatorname{SRF} X \sum_{n}\left[\operatorname{DCF}_{n} \int_{t}^{t+15} C_{g n}(t) d t\right]
$$

where: $D_{g s}$ is the dose equivalent during the period; SRF is the a surface roughness factor $(0.82) ; \mathrm{DCF}_{n}$ is the radionuclide $n$ specific groundshine dose conversion factor; $C_{g n}$ is the radionuclide $n$ surface concentration; $t$ is the time.

Because of the different nature of deterministic and stochastic effects, two types of dose quantity are needed to be able to decide, which protective actions should be implemented, namely projected dose and avertable dose. The relevant quantity for expressing the risk of deterministic effects is the projected dose, i.e. the total dose received via all pathways over a period of time from the beginning of the accident. The projected dose is the total dose to be expected if no protective or remedial action is taken. The avert- able dose is thus defined as the individual dose to be averted by the countermeasure, and it can be assessed as the difference between the dose to be expected without the countermeasure and that to be expected, if the countermeasure is implemented. The avertable dose can be expressed in units of Sieverts $[\mathrm{Sv}]$. Since the post-intervention total annual dose will be lower than that before intervention, the difference is being the averted dose, $|-\Delta \mathrm{E}|$. The system of protection for interventions is concerned only with the averted doses $|-\Delta \mathrm{E}|$, by evaluating the intervention total annual dose [7] (residual) and not post-intervention annual dose. An intervention will usually be justified when the avertable dose, $|-\Delta \mathrm{E}|$, is greater than an optimized intervention level, IL, i.e:

If $|-\Delta \mathrm{E}|>\mathrm{IL} \Rightarrow$ introduce the specified countermeasure [8].

Intervention level is the level of avertable dose, at which a specific protective action or remedial action is taken in an emergency exposure situation or a chronic exposure situation [9]. An intervention level (IL) relates to the specific countermeasure, which required mitigating the consequences from an accidental release of radionuclides (sheltering, evacuation and relocation etc.).

The obtained results of using RASCAL model are used for supporting the decision maker to put in place the necessary protective planning actions.

\section{Results and discussion}

Gamma exposure rate from the time since release to atmosphere started was measured for the distances $4.8,8,16$ and $24.3 \mathrm{~km}$, respectively by the authors using RASCAL model as shown in Fig. 1, as evacuation and sheltering zones. It is obvious that the plume for the distance 4.8, 8 and $16 \mathrm{~km}$ arrived quickly and the release rate started with the beginning of the accident. Also the release rate reduced at the third hour due to intervention action is taken to reduce the leak rate from $10 \% / \mathrm{h}$ to $0.1 \% / \mathrm{h}$ concerning that the value of reduction dose represents the avertable dose. The release rate started at the distance $24.3 \mathrm{~km}$ after $2 \mathrm{~h}$ from the beginning of the accident and also affected by the intervention action after $2 \mathrm{~h}$ and $15 \mathrm{~min}$. Consequently, the avertable doses decrease with the increase of distance far away from the release point.

\section{Emergency exposure situation}

Early phase dose calculations may be made from either an average air concentration measured during plume passage or a ground concentration measurement made immediately after plume passage. These dose calculations assume that the measurement represents the radiological conditions during plume passage and that an individual is exposed to the plume during its passage and to radiation from the surface for the period of plume passage plus the remainder of a 96-h period. The plume is assumed to be present at the measurement location for the duration of 
Receptor location: $190: 4.83 \mathrm{~km}$ (from release point)

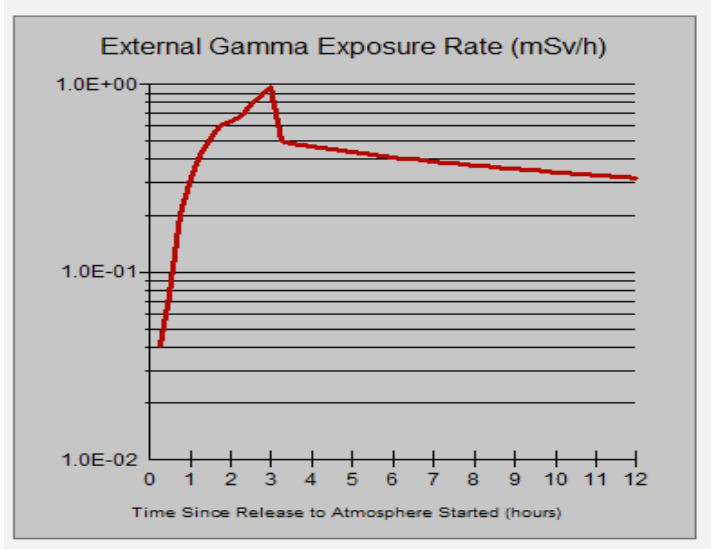

Receptor location: $190^{*}, 16.09$ km (from release point)

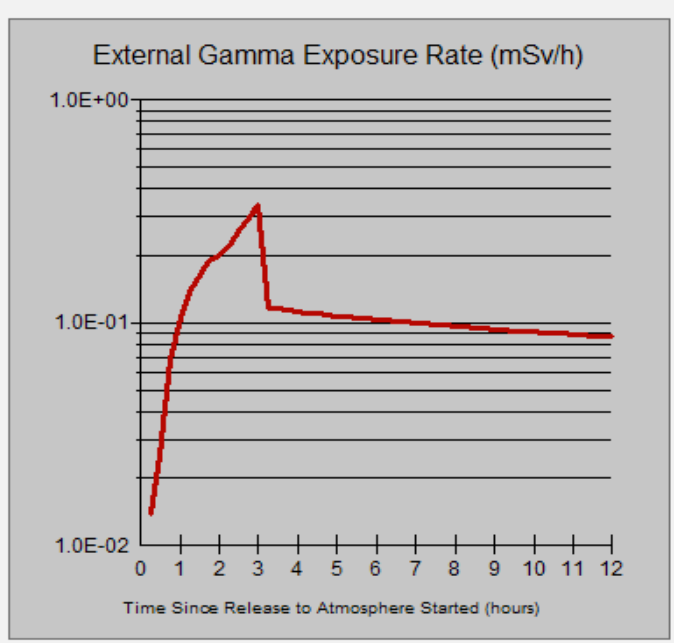

Receptor location: 190: 8.05 km (from release point)

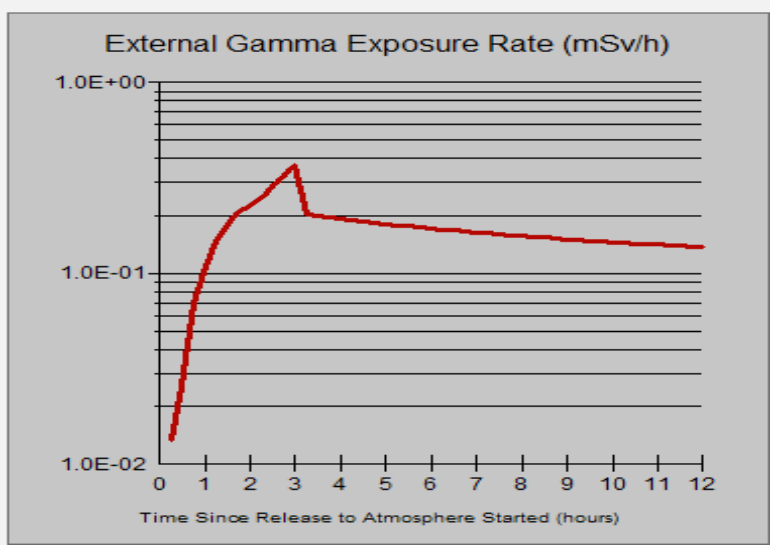

Receptor location: $\mathbf{1 8 9 . 5} \mathrm{deg} . \mathbf{2 4 . 3 3} \mathbf{~ k m}$ (from release point)

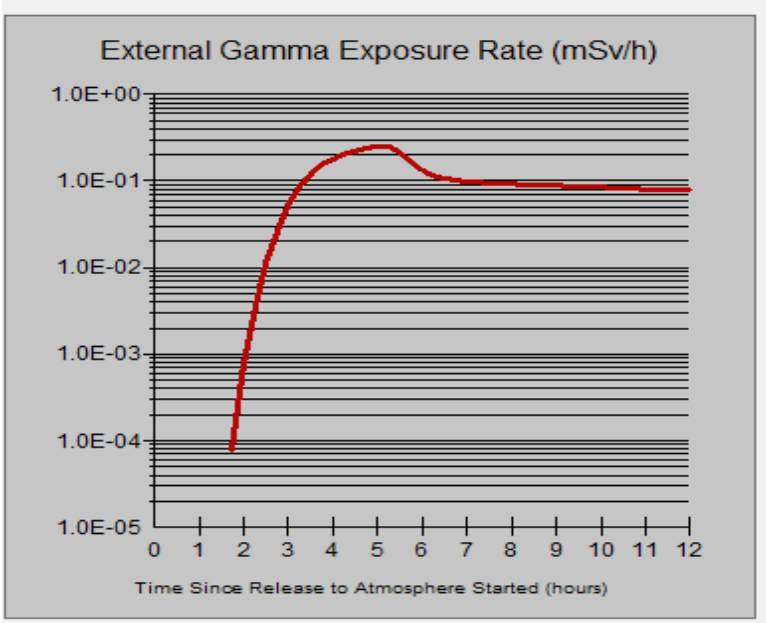

Fig. 1. External gamma exposure rate (in $\mathrm{mSv} / \mathrm{h}$ ) since release for $12 \mathrm{~h}$.

the release, and the concentration in the plume is assumed to be constant during plume passage.

When air concentration measurements are used to estimate early phase doses, the dose estimates for the period of plume passage have three components - a submersion dose, an inhalation dose and a groundshine dose. The early phase doses for the period following plume passage also have three components - a groundshine dose from surface contamination and inhalation and submersion doses from resuspended activity. The submersion dose from resuspended activity is generally negligible.

Early phase dose data represented in Table 1.

Surface concentration for iodine-131 and cesium-137 was calculated and represented in Table 2 at distance close to the plant up to distance $16 \mathrm{~km}$
(PAZ and UPZ, respectively). It is clear that in distances $16 \mathrm{~km}$, the surface concentration activities of iodine-131 and Cs-137 are greater than $10 \mathrm{kBq} / \mathrm{m}^{2}$ and $2 \mathrm{kBq} / \mathrm{m}^{2}$, respectively. Immediately restriction for food and milk are implemented.

BSS recommends iodine prophylaxis uses if avertable dose to thyroid is $100 \mathrm{mSv}$ and $\mathrm{WHO}$ recommends use for children, if avertable dose is $10 \mathrm{mSv}$, but does not recommend for adults over 40 years. $130 \mathrm{mg} \mathrm{KI}$ tablet daily for 1-2 days to adults and potassium perchlorate $400 \mathrm{mg}$ for people with iodine sensitivity [10].

The TEDE is calculated assuming that no protective actions, such as evacuation or sheltering are taken. Also, the calculations assume that people are outdoors during plume passage and will remain

Table 1. Early phase dose data (in Sv)

\begin{tabular}{lccc}
\hline \multirow{2}{*}{ Components } & Plume & \multicolumn{2}{c}{ Post } \\
\cline { 2 - 4 } & Passage & Plume & Total \\
\cline { 2 - 4 } & $(1 \mathrm{~h})$ & $(95 \mathrm{~h})$ & $(96 \mathrm{~h})$ \\
\hline Total effective dose & & & $7.32 \mathrm{E}-03$ \\
pathway & $6.63 \mathrm{E}-03$ & $6.88 \mathrm{E}-04$ & $6.39 \mathrm{E}-04$ \\
groundshine & $3.87 \mathrm{E}-06$ & $6.35 \mathrm{E}-04$ & $3.92 \mathrm{E}-05$ \\
submersion & $3.88 \mathrm{E}-05$ & $5.18 \mathrm{E}-07$ & $6.64 \mathrm{E}-03$ \\
effective inhalation & $6.59 \mathrm{E}-03$ & $1.58 \mathrm{E}-03$ & $\underline{2.08 \mathrm{E}-01}$ \\
Thyroid inhalation & $2.06 \mathrm{E}-01$ & & \\
\hline
\end{tabular}


Table 2. Surface concentration for ${ }^{131} \mathrm{I}$ and ${ }^{137} \mathrm{Cs}$ for PAZ and UPZ zones

\begin{tabular}{rccc}
\hline $\begin{array}{c}\text { Distance } \\
{[\mathrm{km}]}\end{array}$ & $\begin{array}{c}\text { Surface concentration } \\
\text { of }{ }^{131} \mathrm{I}\left[\mathrm{KBq} / \mathrm{m}^{2}\right]\end{array}$ & $\begin{array}{c}\text { Surface concentration } \\
\text { of }{ }^{137} \mathrm{Cs}\left[\mathrm{KBq} / \mathrm{m}^{2}\right]\end{array}$ & Protective action \\
\hline 0.8 & $6.62 \times 10^{-5}$ & $5.62 \times 10^{4}$ & \\
1.6 & $1.81 \times 10^{-5}$ & $1.54 \times 10^{4}$ & Restrict immediate consumption \\
2.4 & $8.00 \times 10^{-4}$ & $6.96 \times 10^{3}$ & of potentially contaminated food \\
3.2 & $4.77 \times 10^{-4}$ & $4.03 \times 10^{3}$ & and milk in area until samples are \\
4.8 & $2.15 \times 10^{-4}$ & $1.83 \times 10^{3}$ & evaluated (IAEA-TECDOC-955) \\
8.0 & $9.44 \times 10^{-3}$ & $8.07 \times 10^{2}$ & \\
11.0 & $7.25 \times 10^{-3}$ & $6.22 \times 10^{2}$ & \\
16.0 & $6.30 \times 10^{-3}$ & $5.48 \times 10^{2}$ & \\
\hline
\end{tabular}

Table 3. The code calculation results of radiological consequences for PWR accident

\begin{tabular}{|c|c|c|c|c|c|}
\hline \multirow{2}{*}{$\begin{array}{c}\text { Distance } \\
{[\mathrm{km}]}\end{array}$} & \multicolumn{2}{|c|}{$\begin{array}{c}\text { Projected dose } \\
{[\mathrm{Sv}]} \\
\end{array}$} & \multirow{2}{*}{$\begin{array}{c}\begin{array}{c}\text { Avertable dose } \\
{[\mathrm{Sv}]}\end{array} \\
\Delta \mathrm{E}\end{array}$} & \multirow{2}{*}{$\begin{array}{l}\text { Ambient dose } \\
\text { rate in the plume } \\
{[\mathrm{mSv} / \mathrm{h}]}\end{array}$} & \multirow{2}{*}{$\begin{array}{l}\text { Intervention } \\
\text { action }\end{array}$} \\
\hline & $\begin{array}{c}\text { Before } \\
\text { intervention }\end{array}$ & $\begin{array}{c}\text { After } \\
\text { intervention }\end{array}$ & & & \\
\hline 0.8 & 6.50 & 1.30 & 5.20 & 13.0 & Evacuation* \\
\hline 1.6 & 1.80 & 0.35 & 1.45 & 2.8 & Evacuation \\
\hline 2.4 & 0.79 & 0.15 & 0.64 & 1.25 & Evacuation \\
\hline 3.2 & 0.46 & 0.089 & 0.371 & 0.72 & Evacuation \\
\hline 4.8 & 0.21 & 0.048 & 0.262 & 0.32 & Evacuation \\
\hline 8.0 & 0.09 & 0.017 & 0.073 & 0.14 & Sheltering \\
\hline 11.0 & 0.07 & $13 \times 10^{-3}$ & $57 \times 10^{-3}$ & 0.10 & Sheltering \\
\hline 16.0 & $61 \times 10^{-3}$ & $12 \times 10^{-3}$ & $49 \times 10^{-3}$ & 0.086 & $\begin{array}{c}\text { Sheltering-take thyroid } \\
\text { blocking agent }\end{array}$ \\
\hline 24.0 & $45 \times 10^{-3}$ & $9.5 \times 10^{-3}$ & $35.5 \times 10^{-3}$ & 0.078 & $\begin{array}{l}\text { Sheltering-take thyroid } \\
\text { blocking agent }\end{array}$ \\
\hline 32.0 & $34 \times 10^{-3}$ & $7.3 \times 10^{-3}$ & $2.6 \times 10^{-3}$ & 0.056 & $\begin{array}{c}\text { Sheltering-take thyroid } \\
\text { blocking agent }\end{array}$ \\
\hline 48.3 & $23 \times 10^{-3}$ & $5.7 \times 10^{-3}$ & $17.3 \times 10^{-3}$ & 0.049 & - \\
\hline 64.4 & $14 \times 10^{-3}$ & $4.4 \times 10^{-3}$ & $9.6 \times 10^{-3}$ & 0.0386 & - \\
\hline
\end{tabular}

*Until evacuated people should be instructed to stay inside with their windows closed.

outdoors for 4 days after the radionuclides have been deposited. Consequently, they will expose to ground shine from the deposited radionuclides. Thus, the early phase TEDE that code calculates is larger than the TEDE that would be expected for people, who took protective actions or who continued their normal activities (spending much time indoors).

To determine if doses without any protective actions would exceed the environmental protective action (EPA) guides, the code calculates dose assuming that no intervention actions are taken to reduce doses. The required intervention for protective actions is based on the calculated TEDE that would be received if no protective actions of any type were taken, even actions such as simply spending some time indoors.

Figure 2 represents the distribution of the projected dose (TEDE) from release point to distance

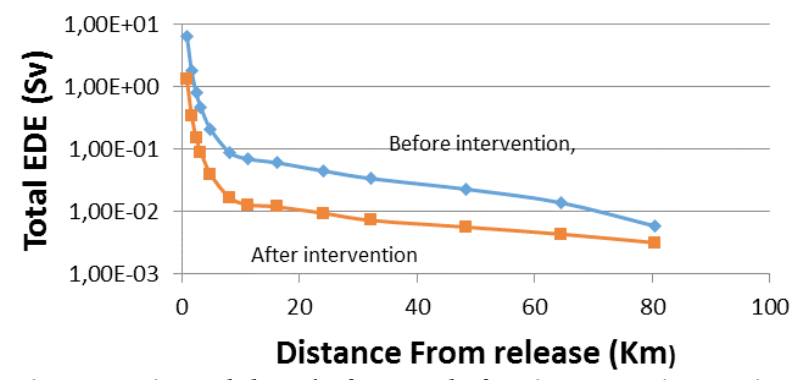

Fig. 2. Projected dose before and after intervention action with distance. closed to $80 \mathrm{~km}$ far away. The total dose received via all pathways over a period of time $(12 \mathrm{~h})$ from the beginning of the accident before and after intervention countermeasures was represented. It is illustrating quite change of the doses slightly with the distance taking in to consideration the known conservatism in weather category. It is clear that the projected dose is greater than $0.5 \mathrm{~Sv}$ in the beginning of the accident for zone $3 \mathrm{~km}$ and $4.8 \mathrm{~km}$, which is precautionary protective action zone (PAZ), so evacuation should be immediately implemented and iodine tablets distributed for blocking against absorption of the released radionuclides. For the zone at distance $6 \mathrm{~km}$ up to $23 \mathrm{~km}$ the projected dose is greater than $10 \mathrm{mSv}$, so the planning of urgent protective action zone (UPZ) is implemented by sheltering at large buildings and effectiveness monitoring with distribution of iodine tablets [11].

At distances, the measured doses do not exceed upper bounds of intervention level intervals the countermeasures are not needed to be introduced, i.e. at distances where the dose is lower than $50 \mathrm{mSv}$ for zone of sheltering and is lower than $500 \mathrm{~Sv}$ for evacuation zone.

From RASCAL results in this our simulation study, one can conclude the avertable dose, gamma exposure rate and the intervention action which should be taken according to ICRP recommendation criteria as shown in Table 3. Although the PAG is 
expressed as a range of $10-50 \mathrm{mSv}$, it is emphasized that, under normal conditions, evacuation of members of the general population should be initiated for most incidents at a projected dose of $10 \mathrm{mSv}$. Sheltering (not evacuation) may be preferable in some situations as a protective action for certain public groups. In addition, under unusually hazardous environmental conditions, use of sheltering at projected doses up to $50 \mathrm{mSv}$ to the general population (and up to $100 \mathrm{mSv}$ to special groups) may become justified. From Table 3, it is obvious that these values will not be exceeded at the distance greater than $25 \mathrm{~km}$ from the plant.

\section{Existing exposure situation}

Intermediate phase dose calculations is the major countermeasures in the later phases of an accident for implementing relocation/resettlement, foodstuff restrictions and cleanup of contaminated land. Relocation refers to the removal of people from the area affected by an accident for a longer period of time (weeks, months or years) to avert exposures from radioactive material deposited on the ground. In a situation where people have been evacuated from affected areas, the authorities would have to consider the following possibilities to be implemented as existing exposure situation: (a) allow people to return to the area without restrictions; (b) allow people to return to the area under controlled conditions and (c) prohibit people to return to the area due to high levels of contamination on ground and building surfaces.

After an accident, the levels of contamination in foods will vary markedly according to many factors, e.g. the type of food, the pattern of deposition, the physical and biological half-lives of the radionuclides, soil types, and agricultural practices [5].

The results of field measurement of dose model would normally be used after releases had been stopped to determine whether the area is habitable or long-term relocation is needed for residents. The model estimates doses based upon measurements of ground contamination depending on the "Environment Protective Action (EPA) Guide".

Two EPA pathways are considered: groundshine and inhalation due to re-suspension. Both pathways are affected by weathering. The material becomes less accessible through time as natural processes work. The EPA (EPA, 1992) determines the following limits for long term relocation: 1 st year PAG = $20 \mathrm{mSv}$, 2nd year or any subsequent year objective $=5 \mathrm{mSv}$.

RASCAL results are far below the EPA PAGs, which refer to the intermediate phase to be existing exposure situation. Based on those results, people can immediately return to their homes in the area. For a typical 'reactor mix' of radionuclides, if the first-year dose is below the PAGs then the second and 50 years doses will be below PAGs as well. Also, the groundshine dose will usually dominate. From Tables 4, 5 and 6 , it is obvious that the dose after accident (at long term), still higher than relocation limits so countermeasures must be taken into account.

\section{Conclusion}

It is essential to have clear control and command arrangements for preparedness and response organizations, government and international organizations. The international guidance is needed an operational criteria (e.g. OIL) to aid decision making during

Table 4. TEDE (in Sv) at long term phase

\begin{tabular}{lcll}
\hline \multicolumn{1}{c}{ Pathway } & 1st year & 2nd year & 50 years \\
\hline Groundshine & $3.00 \mathrm{E}-02$ & $1.98 \mathrm{E}-02$ & $3.83 \mathrm{E}-01$ \\
Submersion & $2.61 \mathrm{E}-06$ & $4.83 \mathrm{E}-09$ & $2.66 \mathrm{E}-06$ \\
Effective inhalation & $3.22 \mathrm{E}-04$ & $4.18 \mathrm{E}-07$ & $3.26 \mathrm{E}-04$ \\
Total & $3.03 \mathrm{E}-02$ & $1.98 \mathrm{E}-02$ & $3.83 \mathrm{E}-01$ \\
\hline
\end{tabular}

Table 5. TEDE remainder intermediate phase

\begin{tabular}{rccc}
\hline & \multirow{2}{*}{$\begin{array}{c}\text { Delay before } \\
\text { return }\end{array}$} & \multicolumn{2}{c}{ TEDE remainder [Sv] $(168 \mathrm{~h} /$ wk in area with 0\% in building) } \\
\cline { 2 - 4 } & 1 st year & 2 nd year & 50 years \\
\hline $0 \mathrm{~d}$ & $3.03 \mathrm{E}-02$ & $1.98 \mathrm{E}-02$ & $3.83 \mathrm{E}-01$ \\
$1 \mathrm{~d}$ & $2.96 \mathrm{E}-02$ & $1.98 \mathrm{E}-02$ & $3.83 \mathrm{E}-01$ \\
$2 \mathrm{~d}$ & $2.90 \mathrm{E}-02$ & $1.98 \mathrm{E}-02$ & $3.82 \mathrm{E}-01$ \\
$4 \mathrm{~d}$ & $2.80 \mathrm{E}-02$ & $1.98 \mathrm{E}-02$ & $3.81 \mathrm{E}-01$ \\
$7 \mathrm{~d}$ & $2.67 \mathrm{E}-02$ & $1.98 \mathrm{E}-02$ & $3.80 \mathrm{E}-01$ \\
$10 \mathrm{~d}$ & $2.56 \mathrm{E}-02$ & $1.98 \mathrm{E}-02$ & $3.79 \mathrm{E}-01$ \\
$14 \mathrm{~d}$ & $2.45 \mathrm{E}-02$ & $1.98 \mathrm{E}-02$ & $3.78 \mathrm{E}-01$ \\
$30 \mathrm{~d}$ & $2.19 \mathrm{E}-02$ & $1.98 \mathrm{E}-02$ & $3.75 \mathrm{E}-01$ \\
$60 \mathrm{~d}$ & $1.94 \mathrm{E}-02$ & $1.98 \mathrm{E}-02$ & $3.72 \mathrm{E}-01$ \\
$90 \mathrm{~d}$ & $1.73 \mathrm{E}-02$ & $1.98 \mathrm{E}-02$ & $3.70 \mathrm{E}-01$ \\
$180 \mathrm{~d}$ & $1.14 \mathrm{E}-02$ & $1.98 \mathrm{E}-02$ & $3.64 \mathrm{E}-01$ \\
$270 \mathrm{~d}$ & $5.71 \mathrm{E}-03$ & $1.98 \mathrm{E}-02$ & $3.59 \mathrm{E}-01$ \\
$1 \mathrm{y}$ & $0.00 \mathrm{E}+00$ & $1.98 \mathrm{E}-02$ & $3.53 \mathrm{E}-01$ \\
\hline
\end{tabular}


Table 6. Gamma exposure rate and Cs-137* surface concentration intermediate phase. (Cs-137*: nuclide with implicit daughter)

\begin{tabular}{|c|c|c|c|c|c|c|}
\hline \multirow{2}{*}{$\begin{array}{l}\text { Delay before } \\
\text { return }\end{array}$} & \multicolumn{3}{|c|}{$\begin{array}{c}\text { Gamma exposure rate }[\mathrm{mSv} / \mathrm{h}] \text { at return } \\
\text { equal to EPA PAG }\end{array}$} & \multicolumn{3}{|c|}{$\begin{array}{c}\text { Surface concentration of Cs-137* }\left[\mathrm{kBq} / \mathrm{m}^{2}\right] \\
\text { equal to EPA PAG }\end{array}$} \\
\hline & 1st year & 2nd year & 50 years & 1st year & 2nd year & 50 years \\
\hline $0 \mathrm{~d}$ & $2.45 \mathrm{E}-02$ & $9.31 \mathrm{E}-03$ & $4.82 \mathrm{E}-03$ & $1.21 \mathrm{E}+03$ & $3.81 \mathrm{E}+02$ & $2.39 \mathrm{E}+02$ \\
\hline $1 \mathrm{~d}$ & $2.31 \mathrm{E}-02$ & $8.62 \mathrm{E}-03$ & $4.47 \mathrm{E}-03$ & $1.24 \mathrm{E}+03$ & $3.80 \mathrm{E}+02$ & $2.39 E+02$ \\
\hline $2 \mathrm{~d}$ & 2.19E-02 & 8.00E-03 & 4.15E-03 & $1.26 \mathrm{E}+03$ & $3.80 \mathrm{E}+02$ & $2.39 \mathrm{E}+02$ \\
\hline $4 d$ & $1.96 \mathrm{E}-02$ & 6.89E-03 & 3.59E-03 & $1.31 \mathrm{E}+03$ & $3.80 \mathrm{E}+02$ & $2.40 \mathrm{E}+02$ \\
\hline $7 \mathrm{~d}$ & $1.66 \mathrm{E}-02$ & $5.55 \mathrm{E}-03$ & $2.90 \mathrm{E}-03$ & $1.37 \mathrm{E}+03$ & $3.79 E+02$ & $2.40 \mathrm{E}+02$ \\
\hline $10 \mathrm{~d}$ & $1.40 \mathrm{E}-02$ & 4.52E-03 & $2.37 \mathrm{E}-03$ & $1.42 \mathrm{E}+03$ & $3.79 E+02$ & $2.40 \mathrm{E}+02$ \\
\hline $14 \mathrm{~d}$ & $1.14 \mathrm{E}-02$ & 3.51E-03 & $1.84 \mathrm{E}-03$ & $1.48 \mathrm{E}+03$ & $3.78 \mathrm{E}+02$ & $2.40 \mathrm{E}+02$ \\
\hline $30 \mathrm{~d}$ & $6.01 \mathrm{E}-03$ & $1.66 \mathrm{E}-03$ & 8.78E-04 & $1.64 \mathrm{E}+03$ & $3.75 \mathrm{E}+02$ & $2.40 \mathrm{E}+02$ \\
\hline $60 \mathrm{~d}$ & 4.41E-03 & $1.08 \mathrm{E}-03$ & $5.74 \mathrm{E}-04$ & $1.82 \mathrm{E}+03$ & $3.70 \mathrm{E}+02$ & $2.37 \mathrm{E}+02$ \\
\hline $90 \mathrm{~d}$ & 4.67E-03 & $1.02 \mathrm{E}-03$ & $5.45 \mathrm{E}-04$ & $2.01 \mathrm{E}+03$ & $3.65 \mathrm{E}+02$ & $2.35 \mathrm{E}+02$ \\
\hline $180 \mathrm{~d}$ & 6.74E-03 & $9.66 \mathrm{E}-04$ & $5.26 \mathrm{E}-04$ & $2.91 \mathrm{E}+03$ & $3.52 \mathrm{E}+02$ & $2.27 \mathrm{E}+02$ \\
\hline $270 \mathrm{~d}$ & $1.28 \mathrm{E}-02$ & 9.22E-04 & $5.10 \mathrm{E}-04$ & $5.54 \mathrm{E}+03$ & $3.39 E+02$ & $2.20 \mathrm{E}+02$ \\
\hline $1 \mathrm{y}$ & & 8.81E-04 & $4.95 \mathrm{E}-04$ & & $3.27 \mathrm{E}+02$ & $2.14 \mathrm{E}+02$ \\
\hline $1.25 \mathrm{y}$ & & $1.15 \mathrm{E}-03$ & $4.82 \mathrm{E}-04$ & & $4.31 \mathrm{E}+02$ & $2.08 \mathrm{E}+02$ \\
\hline $1.5 \mathrm{y}$ & & $1.69 \mathrm{E}-03$ & $4.71 \mathrm{E}-04$ & & $6.37 \mathrm{E}+02$ & $2.03 E+02$ \\
\hline $1.75 \mathrm{y}$ & & 3.33E-03 & $4.60 \mathrm{E}-04$ & & $1.27 \mathrm{E}+03$ & $1.99 \mathrm{E}+02$ \\
\hline $2 \mathrm{y}$ & & & $4.51 \mathrm{E}-04$ & & & $1.95 \mathrm{E}+02$ \\
\hline $3 y$ & & & 4.23E-04 & & & $1.83 \mathrm{E}+02$ \\
\hline $4 y$ & & & $4.06 \mathrm{E}-04$ & & & $1.75 \mathrm{E}+02$ \\
\hline $5 \mathrm{y}$ & & & $3.96 \mathrm{E}-04$ & & & $1.71 \mathrm{E}+02$ \\
\hline $10 \mathrm{y}$ & & & 3.93E-04 & & & $1.70 \mathrm{E}+02$ \\
\hline $20 \mathrm{y}$ & & & $4.50 \mathrm{E}-04$ & & & $1.94 \mathrm{E}+02$ \\
\hline $30 \mathrm{y}$ & & & $5.77 \mathrm{E}-04$ & & & $2.49 \mathrm{E}+02$ \\
\hline $40 \mathrm{y}$ & & & $9.76 \mathrm{E}-04$ & & & $4.21 \mathrm{E}+02$ \\
\hline
\end{tabular}

emergencies. From studying results, it is noted that thyroid received the highest dose value than other organ, it was about $0.21 \mathrm{~Sv}$ during early phase much higher than a low level of emergency protective guidelines recommendation so iodine prophylaxis used. During early phase calculations assume that people will remain outdoors up to 4 days, where the radionuclides have been deposited. Transition from emergency exposure situation to existing exposure situation may happen at any time during an emergency exposure situation, and may take place at different geographical locations at different times. At the existing emergency situation the dose, still higher than relocation limits by $50 \%$ in the 1 st year so countermeasures must be taken into account. During periods of transition, public opinion and media response shall be closely followed in order to ensure that any concerns be addressed promptly. The exposure level in the long-term after the emergency will necessarily be higher than the background level existing before the accident, which would usually be taken as a reference for comparison.

\section{Nomenclature}

BSS - Basic Safety Series

CEDE - committed effective dose equivalent

DRLs - derived response levels

EPA - environmental protective action

ERDS - Emergency Response Data System

ICRP - International Commission on Radiological Protection

$\begin{array}{ll}\text { IL } & \text { - intervention level } \\ \text { LOCA } & \text { - loss-of-coolant accident } \\ \text { N/R } & \text { - nuclear and radiological } \\ \text { NRC } & \text { - Nuclear Regulatory Commission } \\ \text { OIL } & \text { - operation intervention level } \\ \text { PAG } & \text { - Protective Action Guide } \\ \text { PAZ } & \text { - precautionary protective action zone } \\ \text { RASCAL } & \text { - Radiological Assessment System } \\ & \quad \text { for Consequence Analysis } \\ \text { TEDE } & \text { - total effective dose equivalent } \\ \text { UPZ } & \text { - urgent protective action zone } \\ \text { WHO } & \text { - World Health Organization }\end{array}$

\section{References}

1. Diaz Maurin, F. (2011). Fukushima: Consequences of systemic problems in nuclear plant design. Economic \& Political Weekly (Mumbai), 46(13), 10-12. http:// epw.in/epw/uploads/articles/15865.pdf.

2. International Commission on Radiological Protection. (2009). Application of the Commission's recommendations for the protection of people in emergency exposure situations. (ICRP Publication 109). Ann. ICRP, 39(1)

3. Working Group Special Committee on Nuclear Disaster. (2012). Interim report for reviewing. Regulatory guide: Emergency preparedness for nuclear facilities, nuclear safety commission emergency preparedness guidelines.

4. U. S. Nuclear Regulatory Commission. (2012, March). RASCAL 4: Description of models and methods. Washington, DC: Office of Nuclear Security and Incident Response. (20555-0001).

5. A European manual. (2002). Off-site emergency planning and response to nuclear accidents. 
6. International Commission on Radiological Protection. (1991). Recommendations of the International Commission on Radiological Protection. (Publication 60). Oxford: Pergamom Press.

7. Jensen, P. H. (2012). Justification, optimization and decision - aiding in existing exposure situations. Section of Applied Health Physics, Risø National Laboratory, DK-4000 Roskilde, Denmark.

8. International Atomic Energy Agency. (1996). International basic safety standards for protection against radiation and for the safety of radiation sources. Vienna: IAEA. (Safety Series No. 115).
9. U.S. Nuclear Regulatory Commission. (2002, January). Modeling potential reactor accident consequences. (NUREG/BR-0359).

10. International Atomic Energy Agency. (1997). Generic assessment procedures for determining protective actions during a reactor accident. Vienna: IAEA. (IAEA-TECDOC-955).

11. International Atomic Energy Agency. (2002). Safety requirements in emergency preparedness and response. Vienna: IAEA. (IAEA-SR-GS-R-2). 